\title{
Evaluation of a Zirconium Recycle Scrubber System
}

Nuclear Technology

Research and Development

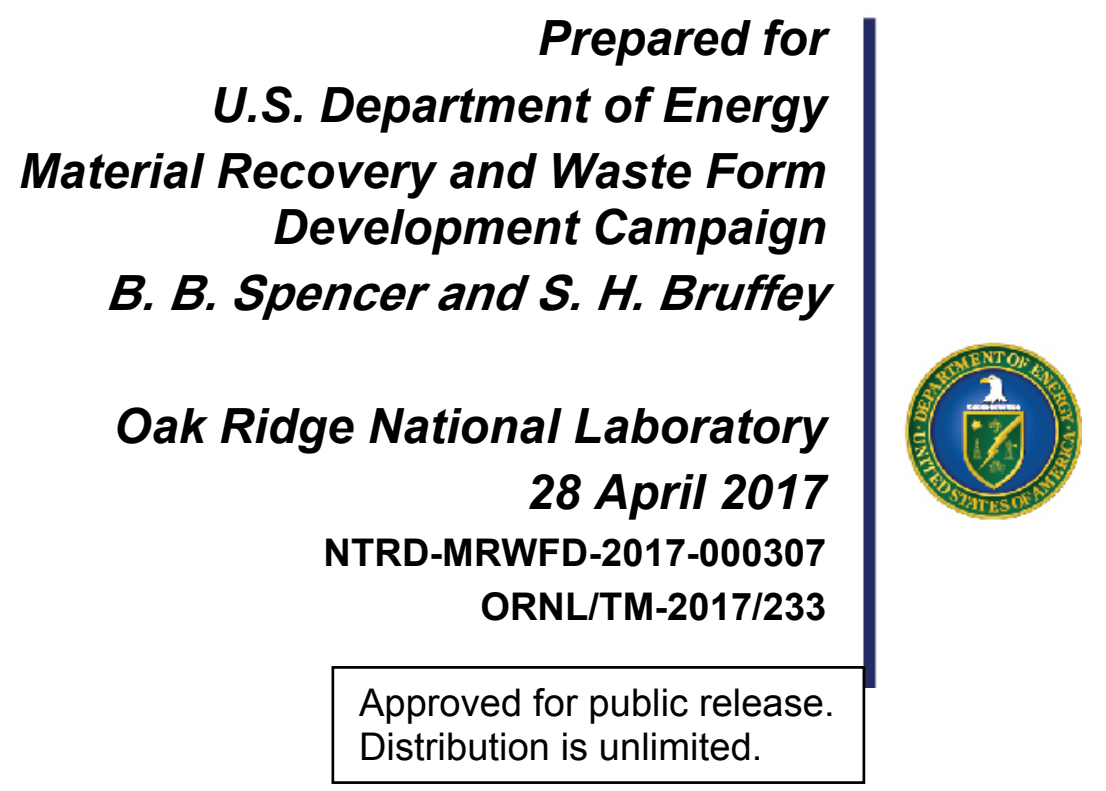





\section{DISCLAIMER}

This information was prepared as an account of work sponsored by an agency of the U.S. Government. Neither the U.S. Government nor any agency thereof, nor any of their employees, makes any warranty, expressed or implied, or assumes any legal liability or responsibility for the accuracy, completeness, or usefulness, of any information, apparatus, product, or process disclosed, or represents that its use would not infringe privately owned rights. References herein to any specific commercial product, process, or service by trade name, trade mark, manufacturer, or otherwise, does not necessarily constitute or imply its endorsement, recommendation, or favoring by the U.S. Government or any agency thereof. The views and opinions of authors expressed herein do not necessarily state or reflect those of the U.S. Government or any agency thereof. 



\section{SUMMARY}

A hot-cell demonstration of the zirconium recycle process is planned as part of the Materials Recovery and Waste Forms Development (MRWFD) campaign. The process treats Zircaloy® cladding recovered from used nuclear fuel with chlorine gas to recover the zirconium as volatile $\mathrm{ZrCl}_{4}$. This releases radioactive tritium trapped in the alloy, converting it to volatile tritium chloride (TCl). To meet regulatory requirements governing radioactive emissions from nuclear fuel treatment operations, the capture and retention of a portion of this $\mathrm{TCl}$ may be required prior to discharge of the off-gas stream to the environment.

In addition to demonstrating tritium removal from a synthetic zirconium recycle off-gas stream, the recovery and quantification of tritium may refine estimates of the amount of tritium present in the Zircaloy cladding of used nuclear fuel. To support these objectives, a bubbler-type scrubber was fabricated to remove the $\mathrm{TCl}$ from the zirconium recycle off-gas stream. The scrubber was fabricated from glass and polymer components that are resistant to chlorine and hydrochloric acid solutions. Because of concerns that the scrubber efficiency is not quantitative, tests were performed using $\mathrm{DCl}$ as a stand-in to experimentally measure the scrubbing efficiency of this unit.

Scrubbing efficiency was $\sim 108 \% \pm 3 \%$ with water as the scrubber solution. Variations were noted when $1 \mathrm{M} \mathrm{NaOH}$ scrub solution was used, values ranged from $64 \%$ to $130 \%$. The reason for the variations is not known.

It is recommended that the equipment be operated with water as the scrubbing solution. Scrubbing efficiency is estimated at $100 \%$. 
This page intentionally left blank 


\section{CONTENTS}

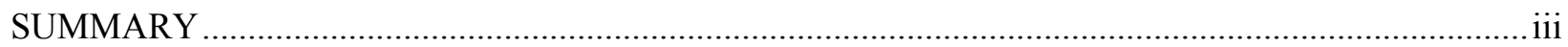

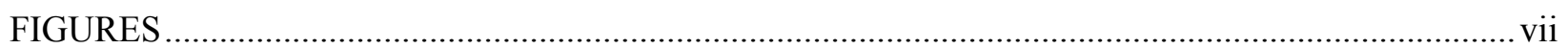

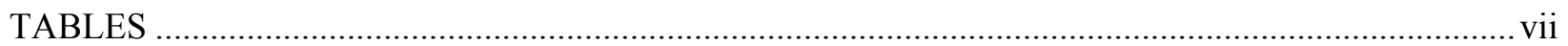

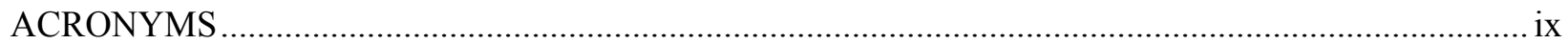

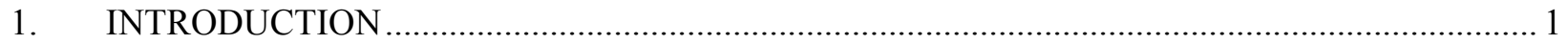

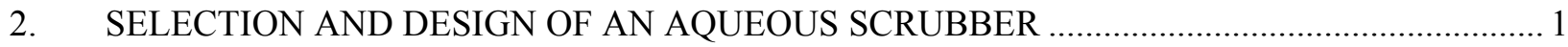

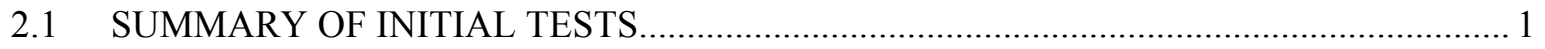

2.2 FABRICATION OF HOT-CELL SCRUBBER …....................................................... 4

3. COLD TEST OF SCRUBBER AND EXPERIMENTAL RESULTS ….................................... 5

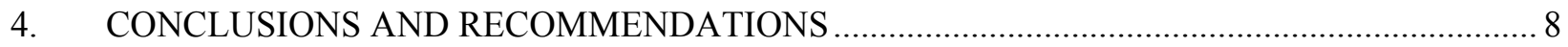

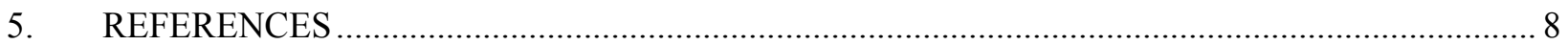


This page intentionally left blank 


\section{FIGURES}

Figure 1. Process for recovery of $\mathrm{HCl}$ from dilute off-gas streams by chemical conversion. ....................2

Figure 2. Flow diagram of scrubber and ancillary equipment. ............................................................... 4

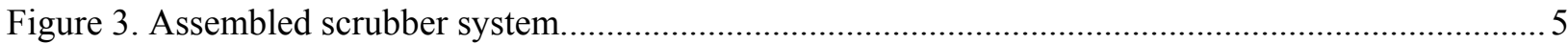

\section{TABLES}

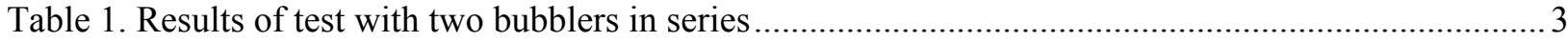

Table 2. Liquid volume vs liquid height in hot-cell scrubber .............................................................. 6

Table 3. Conditions of hot-cell scrubber tests and results ................................................................. 7 
This page intentionally left blank 


\section{ACRONYMS}

MRWFD Materials Recovery and Waste Forms Development (program)

NTRD Nuclear Technology Research and Development Program

ORNL Oak Ridge National Laboratory

sccm standard cubic centimeters per minute

SLAP Standard Light Antarctic Precipitation

UNF used nuclear fuel

UT The University of Tennessee

VSMOW Vienna Standard Mean Ocean Water 
This page intentionally left blank 


\section{EVALUATION OF A ZIRCONIUM RECYCLE SCRUBBER SYSTEM}

\section{INTRODUCTION}

Zircaloy $®$ cladding comprises about $25 \%$ of the mass of used nuclear fuel (UNF). Approximately 98 wt $\%$ of the Zircaloy is high-value, hafnium-free zirconium. As part of the Materials Recovery and Waste Forms Development (MRWFD) campaign [within the Nuclear Technology Research and Development (NTRD) Program] to develop technologies for processing UNF, zirconium recycle is being developed as a technology to further reduce the amount of waste destined for disposal in a geologic repository. Treated cladding could be either recycled or disposed as low-level radioactive waste. Because irradiated zirconium contains a small fraction of radioactive ${ }^{93} \mathrm{Zr}$ activation product, zirconium recovered from UNF might be limited to reuse for nuclear applications, such as making new cladding. Should reuse be uneconomical, it may be possible to decontaminate the recovered zirconium sufficiently from other fission and activation products to qualify it for much less expensive low-level waste disposal.

Recovery of the zirconium and treatment of the off-gases from the recovery process have been previously described in detail, so only a brief summary is provided here. ${ }^{1-3}$ Cladding from UNF may be contaminated with residual adherent fuel, fission recoil fuel fragments embedded in the metal, and gaseous fission products that can diffuse into the metal structure. In particular, part of the tritium produced during irradiation of the nuclear fuel is trapped in the metal of the cladding as zirconium hydride. Treatment of the cladding with hydrogen chloride $(\mathrm{HCl})$ or chlorine $\left(\mathrm{Cl}_{2}\right)$ at temperatures around $400^{\circ} \mathrm{C}$ converts the zirconium to volatile zirconium tetrachloride $\left(\mathrm{ZrCl}_{4}\right)$. Under the current Zircaloy processing baseline, chlorine gas is used to convert the metals to chlorides. The gaseous $\mathrm{ZrCl}_{4} \mathrm{Separates}$ from the nonvolatile fuel fragments and nonvolatile metals (e.g., nickel), effecting a significant radiological decontamination. After separation, cooling condenses or desublimes the $\mathrm{ZrCl}_{4}$ as a solid salt. In addition to zirconium, some of the chlorides of the alloy components of Zircaloy are volatile, e.g., tin tetrachloride $\left(\mathrm{SnCl}_{4}\right)$, and niobium pentachloride $\left(\mathrm{NbCl}_{5}\right)$ or niobium oxychloride $\left(\mathrm{NbOCl}_{3}\right)$, and may be partially condensed along with the zirconium. ${ }^{4}$ Any tritium or tritiated zirconium hydride in the alloy will react to produce tritium chloride $(\mathrm{TCl})$, which remains in the gas stream. The capture and retention of a portion of this $\mathrm{TCl}$ may be required to meet regulatory requirements for the off-gas stream.

A previously reported assessment identified five methods to capture tritium from the off-gas stream of the zirconium recovery process. ${ }^{1,2}$ Of these methods, liquid scrubbing appeared to be the least complex to implement and to require the least amount of further development to support near-term hot cell demonstrations of the zirconium recycle process. The purpose of the work documented in this report was to construct a zirconium recycle off-gas treatment system that is easily operated in the hot cell and to test the effectiveness and efficiency of the system's liquid scrubber in removing TCl from an argon stream containing chlorine at a concentration representative of that used in the zirconium recycle process.

\section{SELECTION AND DESIGN OF AN AQUEOUS SCRUBBER 2.1 SUMMARY OF INITIAL TESTS}

In previous studies, estimates were made of the amount of tritium in irradiated Zircaloy cladding and the composition of the off-gas from an operation to recover the zirconium as $\mathrm{ZrCl}_{4} .{ }^{1-3}$ The quantities of hydrogen isotopes (including tritium) in the cladding are quite small. Reported quantities of tritium are $235-500 \mu \mathrm{Ci} / \mathrm{g}$, ${ }^{5}$ which is equivalent to $24-52 \mathrm{ng} / \mathrm{g}$. During processing of the cladding, the tritium is expected to convert to $\mathrm{TCl}$. The off-gas from the process is expected to be primarily the inert carrier gas 
argon $(\sim 95 \mathrm{v} / \mathrm{v} \%)$, excess chlorine $(\sim 5 \mathrm{v} / \mathrm{v} \%)$, and $\mathrm{HCl}$ arising from all isotopes of hydrogen associated with the cladding, i.e., ${ }^{\text {all }} \mathrm{HCl}$ (a few parts per million by volume). ${ }^{1}$

Several methods were identified to recover $\mathrm{TCl}$ from gaseous streams, including condensation, liquid scrubbing, conversion to water followed by trapping or condensation, adsorption as a binary salt, and physisorption on molecular sieves. Two methods judged to be the most effective for this application were (1) liquid scrubbing using water or aqueous caustic solutions at room temperature and (2) conversion to water with subsequent condensation. Both methods were tested experimentally. In all tests, DCl (i.e., ${ }^{2} \mathrm{HCl}$ ) was used as a stand-in for ${ }^{\text {all }} \mathrm{HCl}$ arising from the cladding, including the radioactive $\mathrm{TCl}$ (i.e., ${ }^{3} \mathrm{HCl}$ ). The lower bound of $\mathrm{DCl}$ concentrations in these experiments was determined by the total gas flow rates to be used in the planned zirconium recycle hot cell demonstrations and by the detection limits of the analytical methods to be used. The concentration of $\mathrm{DCl}$ in the surrogate off-gas stream (up to $2 \% \mathrm{v} / \mathrm{v}$ ) was thus greater than the anticipated concentration of the $\mathrm{TCl}$ component expected in the Zircaloy processing off-gas stream. The results of initial scoping tests for both methods are summarized here, and complete details are provided in previous reports. ${ }^{1,3}$

Two tests of the conversion with condensation method were conducted. ${ }^{1,3}$ The flow sheet is shown in Fig. 1. In both tests the steel wool column was maintained at $150^{\circ} \mathrm{C}$ to enhance the reaction of DCl with

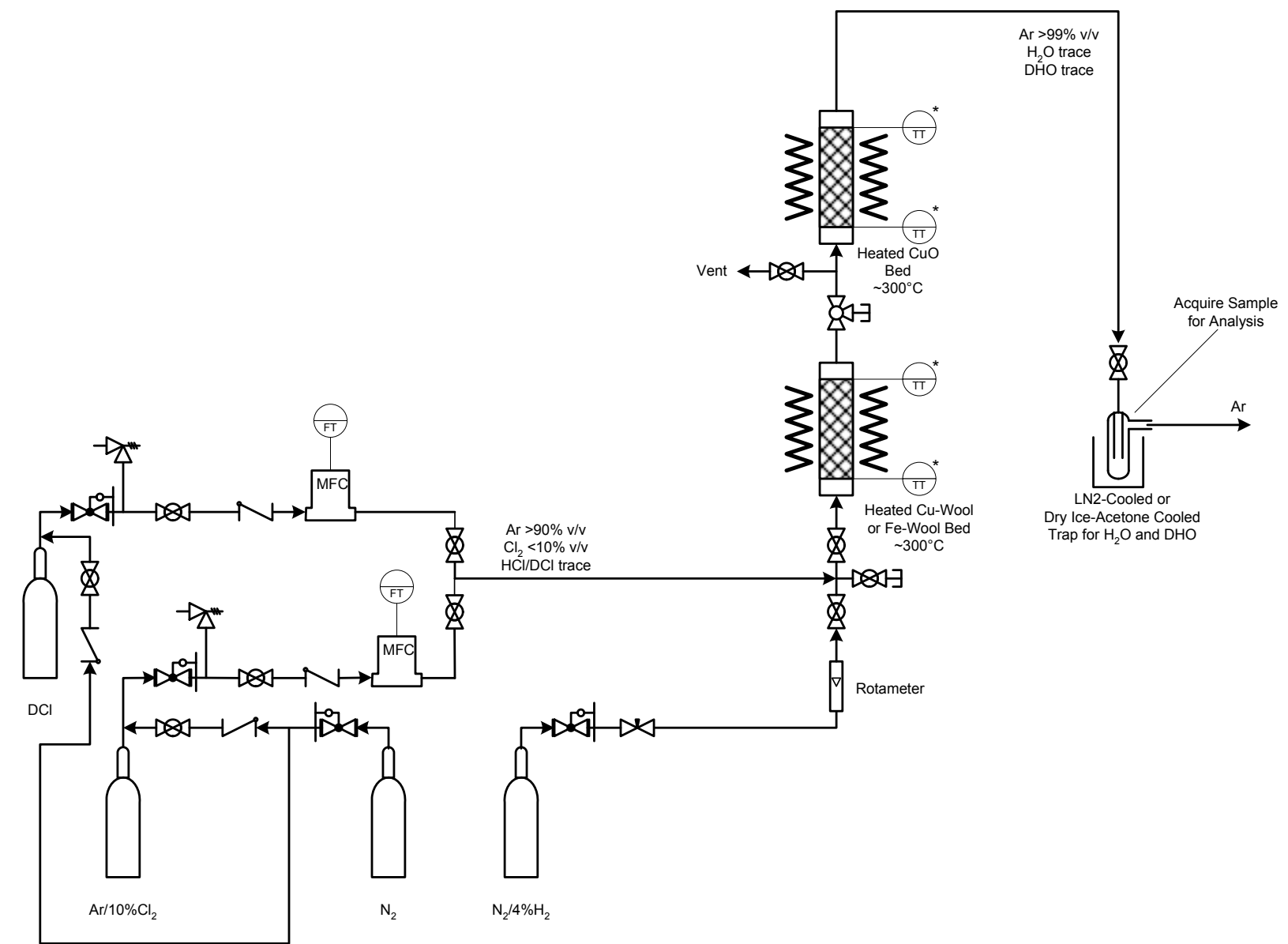

Figure 1. Process for recovery of $\mathrm{HCl}$ from dilute off-gas streams by chemical conversion. (Diagram from Spencer et al., August 2016)

iron, which releases $\mathrm{D}_{2}$. In the first test, the copper oxide $(\mathrm{CuO})$ column was maintained at $250^{\circ} \mathrm{C}$ to convert the $\mathrm{D}_{2}$ to $\mathrm{D}_{2} \mathrm{O}$, and in the second test, the column was maintained at $275^{\circ} \mathrm{C}$. The $\mathrm{DCl}$ concentration in the feed stream was $2 \% \mathrm{v} / \mathrm{v}$ (balance argon). Although $\mathrm{Cl}_{2}$ is estimated to be present at 5 
$\mathrm{v} / \mathrm{v} \%$ in the zirconium recycle off-gas stream, it was not used in these initial tests because its only effect would be to consume more steel wool in the first column. Based on the mass of condensate collected (and presumed to be deuterated water arising only from the $\mathrm{DCl}$ fed to the system), the fractional recovery of D was $28.4 \%$ in the first test and $66.2 \%$ in the second test. A low recovery in the first test may have been caused by loss of some sample during handling.

In the first liquid scrubber test, the scrubber solution was $0.1 \mathrm{M} \mathrm{NaOH}$ solution at room temperature. The scrubber consisted of a simple bubbler with the gas stream introduced to the liquid through a glass frit to obtain good gas dispersion. The frit was submerged to a depth of about $14 \mathrm{~cm}$ (5 in.). Analysis of the solution for an increase in the D concentration above the natural concentration (of $0.015 \mathrm{atom} \%$ ) was used to infer the fractional recovery of $\mathrm{D}$, which was $59.0 \%$.

A test was conducted to ascertain if greater liquid depth in the bubbler would enhance the recovery of $\mathrm{DCl}$. This test was mentioned as a work in progress in a previous report. ${ }^{3}$ Because the analysis of samples is now available, the results are reported here. Two bubblers in series were tested. Both bubblers were charged with $1.0 \mathrm{M} \mathrm{NaOH}$ solution and were operated at room temperature. The frit was submerged $14 \mathrm{~cm}$ (5.5 in.) in the first bubbler and $11 \mathrm{~cm}$ (4.5 in.) in the second bubbler. Gas flow was $200 \mathrm{sccm}$ argon and $4 \mathrm{sccm} \mathrm{DCl}$ and continued for $349 \mathrm{~min}$. The deuterium concentrations in the final solutions were measured in samples sent to the Earth \& Planetary Sciences Lab at the University of Tennessee. In the method used, the isotopic ratio $\mathrm{D} / \mathrm{H}$ is scaled to standard materials: Vienna Standard Mean Ocean Water (VSMOW), which has a $\mathrm{D} / \mathrm{H}$ ratio of 0.00015575 , and Standard Light Antarctic Precipitation (SLAP), which has a $\mathrm{D} / \mathrm{H}$ isotopic ratio of 0.0000891669 . For samples outside the range, dilutions are required that can introduce errors greater than the instrument error.

Deuterium concentrations in the samples of the final scrubber solutions are given in Table 1 along with the calculated efficiency of the bubblers. Duplicate samples of the blanks $(\mathrm{NaOH}$ solution containing natural abundance of D) and solutions from each of the two scrubbers were analyzed to get an estimate of the aggregate error in the results. As shown, the first bubbler scrubbed all the $\mathrm{DCl}$ from the gas stream, with essentially no $\mathrm{DCl}$ reporting to the second bubbler. The reason why the bubbler was more efficient in this test than in the single bubbler test is unclear but could have been caused by a difference in the $\mathrm{NaOH}$ concentration or because the skill in handling the equipment had improved.

Table 1. Results of test with two bubblers in series

\begin{tabular}{|l|c|c|c|c|c|c|}
\hline \multicolumn{1}{|c|}{$\begin{array}{c}\text { Sample } \\
\text { Description }\end{array}$} & $\begin{array}{c}\text { Ar Flow } \\
\text { (sccm)* }\end{array}$ & $\begin{array}{c}\text { DCl Flow } \\
\text { (sccm)* }\end{array}$ & $\begin{array}{c}\text { Runtime } \\
(\mathbf{m i n})\end{array}$ & $\begin{array}{c}\text { Scrub Soln } \\
(\mathbf{m L})\end{array}$ & $\begin{array}{c}\text { D analysis } \\
(\mathbf{D} / \mathbf{H}) * *\end{array}$ & $\begin{array}{c}\text { Scrub Efficiency } \\
\text { (\%) }\end{array}$ \\
\hline $\begin{array}{l}\text { Natural } \mathrm{H}_{2} \mathrm{O} \\
\& \mathrm{NaOH}\end{array}$ & $\mathrm{n} / \mathrm{a}$ & $\mathrm{n} / \mathrm{a}$ & $\mathrm{n} / \mathrm{a}$ & $\mathrm{n} / \mathrm{a}$ & 0.000150645 & $\mathrm{n} / \mathrm{a}$ \\
\hline $\begin{array}{l}\text { Natural, } \\
\text { Duplicate }\end{array}$ & $\mathrm{n} / \mathrm{a}$ & $\mathrm{n} / \mathrm{a}$ & $\mathrm{n} / \mathrm{a}$ & $\mathrm{n} / \mathrm{a}$ & 0.000151064 & $\mathrm{n} / \mathrm{a}$ \\
\hline Scrubber \#1 & 200 & 4 & 349 & 498 & 0.00119739 & 101.1 \\
\hline $\begin{array}{l}\text { Scrubber \#1, } \\
\text { Duplicate }\end{array}$ & 200 & 4 & 349 & 498 & 0.001230523 & 104.3 \\
\hline $\begin{array}{l}\text { Scrubber \#2 } \\
\text { 200 }\end{array}$ & $\begin{array}{c}\text { Residual } \\
\text { from \#1 }\end{array}$ & 349 & 455 & 0.000151588 & 0.065 \\
\hline $\begin{array}{l}\text { Scrubber \#2, } \\
\text { Duplicate }\end{array}$ & 200 & $\begin{array}{c}\text { Residual } \\
\text { from \#1 }\end{array}$ & 349 & 455 & 0.000152133 & 0.11 \\
\hline
\end{tabular}

* Standard conditions for the flow meters are pressure $=1 \mathrm{~atm}$, temperature $=70^{\circ} \mathrm{F}$.

** As reported by Earth \& Planetary Sciences Lab at the University of Tennessee. 


\subsection{FABRICATION OF HOT-CELL SCRUBBER}

The objective of this effort was to fabricate and test the equipment designed for recovering tritium from a planned hot-cell test of the zirconium recycle process. For hot-cell operations, an aqueous scrubber method was selected to implement the recovery of tritium from the off-gas of the upcoming zirconium recycle experiment. This selection was strongly driven by the simple hardware required for implementation and because it requires minimal electrical services. ${ }^{3}$ Because of the need to handle chloride-based acid gases, a decision was made to construct the scrubber with primarily glass and polymer components. Some metal connections were needed to interface to the hot cell equipment used to process the Zircaloy.

The general flow diagram of the scrubber and ancillary gas treatment equipment is shown in Fig. 2 . The major components include a glass knock-out pot to collect particulate that may be entrained in the gas stream, a glass bubbler column, a glass dip-tube with integral dispersion frit for admitting the gases, and a glass vessel to hold soda lime to neutralize residual chlorine before the gas is released to the hot cell.

Total gaseous discharge rates from the zirconium recycle process are approximately the same as those used in the prior bubbler tests, i.e., $\sim 200 \mathrm{sccm}$. Nevertheless, a taller scrubber was selected from off-theshelf, commercially available glass components. Also, the column section of the scrubber is about $50 \%$ larger in diameter (at an ID of $80 \mathrm{~mm}$ ) than the simple bubblers used in prior tests (ID about $53 \mathrm{~mm}$ ), and the dip tube is also larger in diameter. A valve is installed at the bottom of the bubbler to collect samples and to drain the column. The assembled system is shown in Fig. 3.

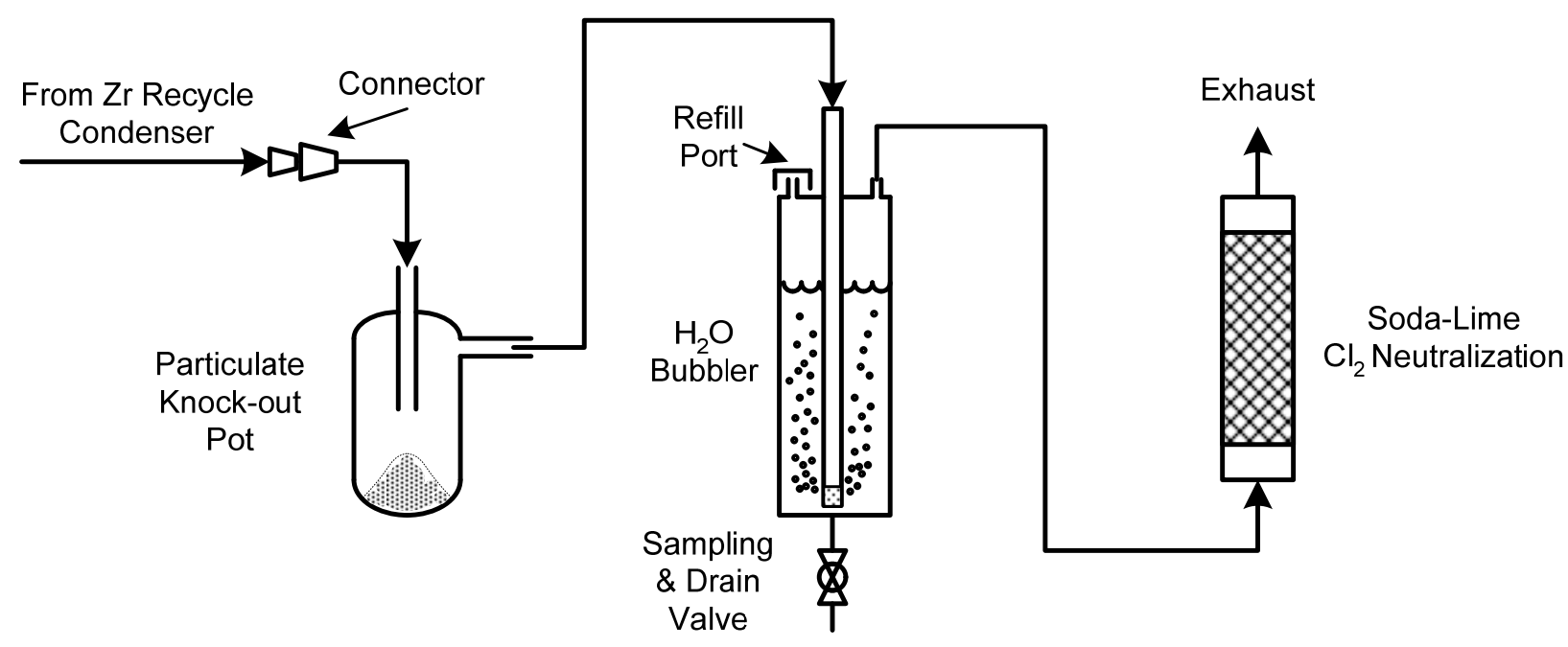

Figure 2. Flow diagram of scrubber and ancillary equipment. 


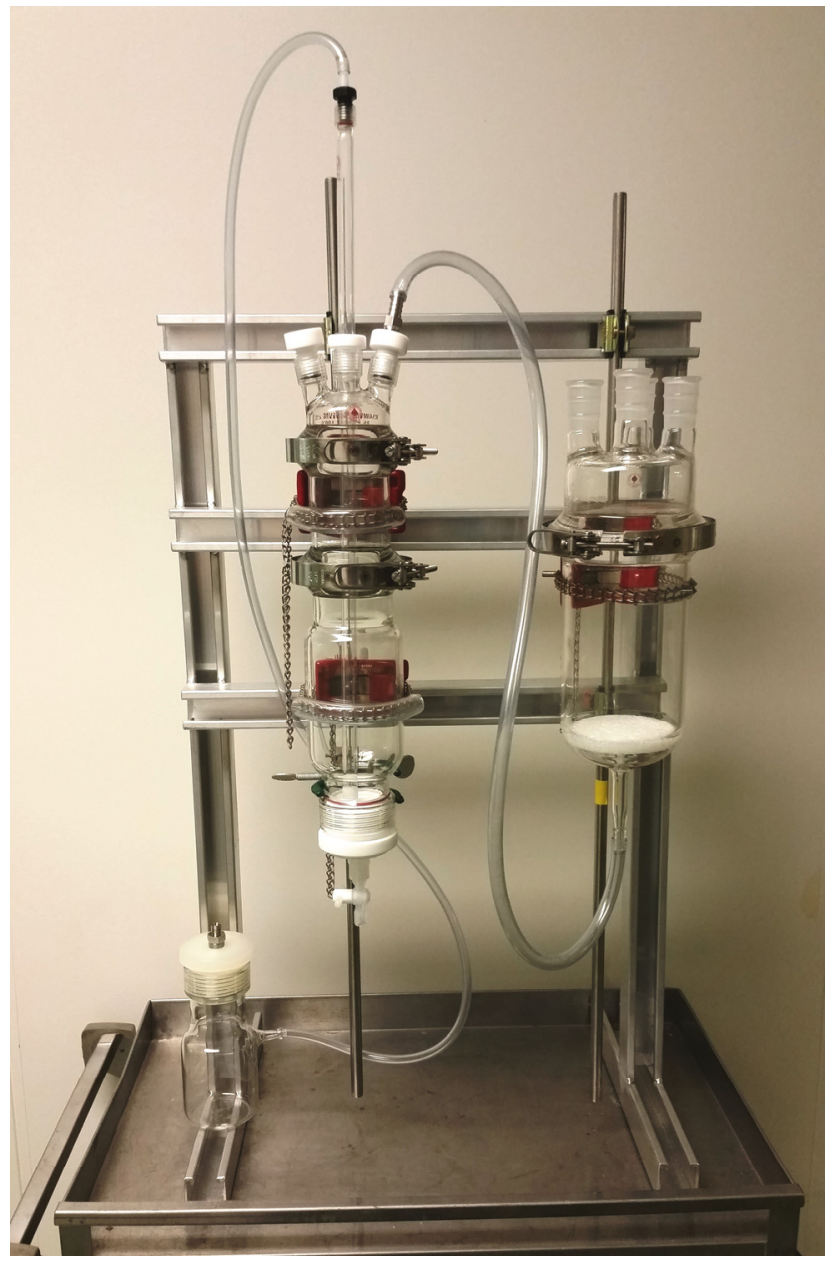

Figure 3. Assembled scrubber system.

\section{COLD TEST OF SCRUBBER AND EXPERIMENTAL RESULTS}

The height of liquid in the scrubber column was measured as a function of the volume of water in the column; data are shown in Table 2. Because the column diameter ranges from about $60 \mathrm{~mm}$, in sections near joints, to $80 \mathrm{~mm}$, in the main body of the column, the volume vs liquid height is nonlinear. The differences in diameter are apparent in Fig. 3. The gas dispersion frit at the end of the dip tube was positioned about $6 \mathrm{~mm}(1 / 4 \mathrm{in}$.) from the bottom of the column. Since the frit is itself about $19 \mathrm{~mm}(3 / 4 \mathrm{in}$.) in length, gas is discharged at heights of between $6 \mathrm{~mm}(1 / 4 \mathrm{in}$.) and $25 \mathrm{~mm}(1 \mathrm{in}$.) from the bottom of the column. These data permit calculation of the liquid scrubbing height.

Tests of the scrubber were conducted using the gas delivery system previously described. ${ }^{3}$ Scrubbing liquids were either deionized water or $1.0 \mathrm{M} \mathrm{NaOH}$ solutions. The volume of scrubbing liquid charged to the column was around $900 \mathrm{~mL}$ in most cases. Other than the scrubbing liquid, the varied parameters were $\mathrm{DCl}$ flow rate, collection time, and two different compositions of diluent gas (i.e., either argon or $10 \% \mathrm{Cl}_{2}$ /balance Ar). Scrubber temperature was always room temperature, which was about $23^{\circ} \mathrm{C}$. No accumulation of liquid droplets in the discharge line was observed, indicating no aerosol escaped the scrubber. Table 3 summarizes the test conditions and the calculated fractional efficiency of the test column. 
Table 2. Liquid volume vs liquid height in hot-cell scrubber

\begin{tabular}{|c|c|}
\hline Water Volume (mL) & Water Height (cm) [in.] \\
\hline 0 & {$[0$} \\
\hline 100 & $3.18\left[1 \frac{1 / 4}{4}\right]$ \\
\hline 200 & $5.72\left[2 \frac{1 / 4}{4}\right]$ \\
\hline 300 & $7.94\left[3^{1 / 8}\right]$ \\
\hline 400 & $9.84\left[3^{7} / 8\right]$ \\
\hline 500 & $11.75\left[4^{5 / 8}\right]$ \\
\hline 600 & $13.65\left[5^{3} / 8\right]$ \\
\hline 700 & $16.19\left[6^{3} / 8\right]$ \\
\hline 800 & $19.05\left[7 \frac{1}{2}\right]$ \\
\hline 900 & $22.86[9]$ \\
\hline 1000 & $26.35\left[10^{3} / 8\right]$ \\
\hline
\end{tabular}

Based on the laboratory data and deuterium concentration, the calculated scrubber efficiency was a little over $100 \%$ in four out of five tests using water as the scrubbing liquid. The indicated error is of a similar order of magnitude as seen with the two-bubblers-in-series test reported in Table 1. One outlier shows $\sim 53 \%$ efficiency. Calculations were made to estimate the holdup of $\mathrm{DCl}$ in the delivery lines, which indicated the holdup may have affected the results by an average of $\sim 3 \%$. The mean of the other four results is 108.2 with a standard deviation of 2.65 . Because the $53 \%$ figure is more than 3 standard deviations from the mean, it may be discarded.

When $1 M \mathrm{NaOH}$ solution is used as the scrubbing liquid, larger variations in the scrubbing efficiency are observed. Samples 22, 23, and 24 are from one experimental test, with samples 22 and 23 taken at intermediate run times and sample 24 taken at the end of the run. The situation is similar for samples 26 , 27, and 28. In the remaining tests using $1 \mathrm{MNaOH}$ solution, samples were taken at the end of the run. The variations seem to be related to the use of $\mathrm{NaOH}$ scrubbing solution. Sufficient chlorine was fed in the longer running tests to consume about half the $\mathrm{NaOH}$, assuming full conversion. Reaction of chlorine with the caustic and water produces $\mathrm{Na}-\mathrm{H}-\mathrm{O}-\mathrm{Cl}$ compounds, for example $\mathrm{NaOCl}, \mathrm{NaCl}$, and $\mathrm{HClO}$, which may have degraded scrubbing performance, but there is insufficient data to verify this. 
Table 3. Conditions of hot-cell scrubber tests and results

\begin{tabular}{|c|c|c|c|c|c|c|c|c|}
\hline $\begin{array}{c}\text { Sample } \\
\text { ID }\end{array}$ & $\begin{array}{l}\text { Diluent } \\
\text { gas }\end{array}$ & $\begin{array}{c}\text { Diluent } \\
\text { Flow } \\
\text { (sccm) }\end{array}$ & $\begin{array}{l}\text { DCl Flow } \\
\text { (sccm) }\end{array}$ & $\begin{array}{c}\text { DCl runtime } \\
(\text { min) }\end{array}$ & $\begin{array}{l}\text { Scrubber } \\
\text { Liquid }\end{array}$ & $\begin{array}{c}\text { Scrubber } \\
\text { Solution } \\
(\mathrm{mL})\end{array}$ & $\begin{array}{l}\text { D Analysis } \\
(\mathrm{D} / \mathrm{H})^{* *}\end{array}$ & $\begin{array}{c}\text { Scrubber } \\
\text { Efficiency } \\
(\%)\end{array}$ \\
\hline 4 & $10 \% \mathrm{Cl}_{2} / \mathrm{Ar}$ & 200 & 4 & 293.0 & \multirow{6}{*}{$\mathrm{H}_{2} \mathrm{O}$} & 900 & 0.000663627 & 105.5 \\
\hline 7 & $10 \% \mathrm{Cl}_{2} / \mathrm{Ar}$ & 200 & 4 & 285.0 & & 900 & 0.000668019 & 109.4 \\
\hline 10 & $10 \% \mathrm{Cl}_{2} / \mathrm{Ar}$ & 200 & 1 & 377.0 & & 900 & 0.000315812 & 105.8 \\
\hline 13 & $\mathrm{n} / \mathrm{a}$ & 0 & 4 & 214.0 & & 860 & 0.000346768 & 52.84 \\
\hline 16 & $\mathrm{Ar}$ & 200 & 4 & 192.0 & & 900 & 0.000506799 & 111.9 \\
\hline $18 *$ & $\mathrm{n} / \mathrm{a}$ & $\mathrm{n} / \mathrm{a}$ & $\mathrm{n} / \mathrm{a}$ & $\mathrm{n} / \mathrm{a}$ & & $\mathrm{n} / \mathrm{a}$ & 0.000150345 & \\
\hline 20 & $10 \% \mathrm{Cl}_{2} / \mathrm{Ar}$ & 200 & 4 & 329.0 & \multirow{9}{*}{$1.0 M \mathrm{NaOH}$} & 965 & 0.000660245 & 101.1 \\
\hline 22 & $10 \% \mathrm{Cl}_{2} / \mathrm{Ar}$ & 200 & 4 & 73.0 & & 970 & 0.000238993 & 79.14 \\
\hline 23 & $10 \% \mathrm{Cl}_{2} / \mathrm{Ar}$ & 200 & 4 & 278.0 & & 950 & 0.000429355 & 64.83 \\
\hline 24 & $10 \% \mathrm{Cl}_{2} / \mathrm{Ar}$ & 200 & 4 & 360.0 & & 930 & 0.000631871 & 85.49 \\
\hline 26 & $10 \% \mathrm{Cl}_{2} / \mathrm{Ar}$ & 200 & 1 & 79.0 & & 920 & 0.000188021 & 116.7 \\
\hline 27 & $10 \% \mathrm{Cl}_{2} / \mathrm{Ar}$ & 200 & 1 & 171.0 & & 900 & 0.000195358 & 64.36 \\
\hline 28 & $10 \% \mathrm{Cl}_{2} / \mathrm{Ar}$ & 200 & 1 & 325.0 & & 880 & 0.000255539 & 78.01 \\
\hline 31 & $\mathrm{Ar}$ & 200 & 1 & 260.0 & & 963 & 0.000288002 & 137.4 \\
\hline $33 *$ & $\mathrm{n} / \mathrm{a}$ & $\mathrm{n} / \mathrm{a}$ & $\mathrm{n} / \mathrm{a}$ & $\mathrm{n} / \mathrm{a}$ & & $\mathrm{n} / \mathrm{a}$ & 0.000151029 & \\
\hline
\end{tabular}

* "Blank" sample having natural abundance of deuterium.

** As reported by Earth \& Planetary Sciences Lab at the University of Tennessee.

Note: Samples 22, 23, and 24 are from the same test but were taken from the bubbler at different run times. Similarly,

samples 26, 27 and 28 were from different run times of the same test. 


\section{CONCLUSIONS AND RECOMMENDATIONS}

Previous proof-of-principle demonstrations investigated $\mathrm{HCl}$ capture from a gas stream simulating the effluent from the zirconium recycle process. These tests explored both a conversion-condensation process that can convert $\mathrm{HCl}$ to $\mathrm{H}_{2} \mathrm{O}$ for recovery and aqueous scrubbing for direct $\mathrm{HCl}$ removal. Aqueous scrubbing was judged to be the most suitable process for use in planned hot-cell demonstrations of the zirconium recycle process. In this effort, an aqueous scrubber was fabricated for use in an upcoming hotcell experimental demonstration of the zirconium recycle process used to process used Zircaloy cladding. In this demonstration the recovery of tritium released from the cladding is of interest, both to obtain data on the amount of tritium trapped in the cladding and to demonstrate that the tritium can be removed from the zirconium recycle off-gas stream. The scrubber was fabricated from glass and polymer components that are resistant to chlorine and hydrochloric acid solutions. There is always concern that the scrubber efficiency is less than perfect. Tests were performed using $\mathrm{DCl}$ as a stand-in to experimentally measure the scrubbing efficiency of this unit.

Scrubbing efficiency was consistently high with water scrubbing. Variations were noted when a $1 \mathrm{M} \mathrm{NaOH}$ scrub solution was used; values ranged from $64 \%$ to $130 \%$. The reason for the variations is not known, although it is speculated that some Na-H-Cl-O compounds may have formed that interfered with the sorption of $\mathrm{DCl}$.

It is recommended that the equipment be operated with water as the scrubbing solution. Approximate scrubbing efficiency is estimated at $100 \%$.

\section{REFERENCES}

1. Spencer, B. B., Walker, T. B., Bruffey, S. H., and DelCul, G. D., Capture of Tritium Released from Cladding in the Zirconium Recycle Process, ORNL/TM-2016/444; also FCRD-MRWFD-2016000297, UT-Battelle LLC, Oak Ridge National Laboratory, Oak Ridge, TN, August 2016.

2. Spencer, B. B., Walker, T. B., Bruffey, S. H., and DelCul, G. D., Capture of Tritium Released from Cladding in the Zirconium Recycle Process, ORNL/TM-2016/531; also FCRD-MRWFD-2016000016, UT-Battelle LLC, Oak Ridge National Laboratory, Oak Ridge, TN, September 2016.

3. Bruffey, S. H., Spencer, B. B., and DelCul, G. D., "Removal of Tritium from the Gaseous Effluents Produced by the Recovery of Zirconium from Used Fuel Cladding," American Nuclear Society Annual Meeting 2017, San Francisco CA, June 2017 (abstract accepted).

4. Collins, E. D., DelCul, G. D., Johnson, J. A., Hylton, T. D., Hunt, R. D., Spencer, B. B., and Bradley, E. C., "Engineering-Scale Development/Demonstration of Zirconium Recovery from Used Fuel Cladding," American Nuclear Society Annual Meeting 2017, San Francisco CA, June 2017 (abstract accepted).

5. Robinson, S. M., Chattin. M. R., Giaquinto, J. M., and Jubin, R. T., "Tritium Content in and Release from Pressurized-Water-Reactor Fuel Cladding," Transactions of the American Nuclear Society, Vol. 114, New Orleans, LA, June 12-16, 2016. 